\title{
Nitrogen cycling in sheep
}

By J. V. Nolan, B. W. Norton* and R. A. Leng, Department of Biochemistry and Nutrition, University of New England, Armidale, New South Wales 235 I, Australia

\section{Introduction}

Many of the difficulties in predicting the response of ruminants to supplementation of low-protein diets with non-protein nitrogen (NPN) substances arise because there is a lack of information concerning the quantities of $N$ that recycle between the tissues and the $\mathrm{N}$ pools in the digestive tract.

Various aspects of $\mathrm{N}$ metabolism in ruminants have been examined but usually the investigations have been restricted to intensive examination of one component rather than to more comprehensive consideration of the over-all metabolism of $\mathrm{N}$ and in particular of urea and ammonia $\mathrm{N}$ in intact and feeding animals. Whole animal studies have relied on the use of isotope-tracer techniques and recently major advances have been made using ${ }^{15} \mathrm{~N}$-labelled compounds.

In this paper, aspects of $\mathrm{N}$ cycling between $\mathrm{N}$ pools in the digestive tract and urea in blood in ruminants are discussed in an attempt to define the role of endogenous urea in digestive processes.

\section{Ammonia N cycling within the rumen}

There is a lack of detailed information on the pathways of degradation of proteins and other dietary $\mathrm{N}$ constituents in the rumen but, in general, soluble proteins are degraded through peptides and amino acids to ammonia and fatty acids. Recent measurements of the rate of ammonia production using ${ }^{15} \mathrm{~N}$ (see below) suggest that $50-70 \%$ of the crude protein of a ration is converted to ammonia in the rumen of sheep given diets of dried and chaffed roughages; numerous studies with similar diets using animals with re-entrant cannulas have also indicated that $40-60 \%$ of the dietary crude protein passes undegraded to the abomasum (see Hogan \& Weston, 1970).

Other sources of ammonia in the rumen include urea from blood, salivary proteins, epithelial cells sloughed off the mouth, oesophagus and rumen epithelium and other endogenous proteins entering the mouth such as those from the respiratory tract.

Studies of the dynamics of ${ }^{15} \mathrm{NH}_{4}^{+}$metabolism in the rumen indicated that $50-70 \%$ of the microbial $\mathrm{N}$ was derived from ammonia (Pilgrim, Gray, Weller \&

*Present address: Department of Agriculture, University of Queensland, Brisbane, Queensland 4067, Australia. 
Belling, 1970; Nolan \& Leng, 1972). Peptides and amino acids from the feed therefore probably provide the balance of the $\mathrm{N}$ required for microbial growth.

Ammonia is recycled within the rumen as indicated by compartmental analysis of isotope-dilution curves following intra-ruminal injection of ${ }^{15} \mathrm{NH}_{4}{ }^{+}$salts in sheep fed lucerne-diets (Abe \& Kandatsu, I969; Nolan \& Leng, 1972). The apparent recycling rate of ${ }^{15} \mathrm{~N}$ to the ${ }^{15} \mathrm{NH}_{4}{ }^{+}$pool in the rumen (indicated by the differences between the total production of ammonia and the irreversible loss of ammonia in the rumen) was greater than could be explained by the return of absorbed ammonia $\mathrm{N}$ to the rumen via blood urea (Nolan \& Leng, 1972). This re-entry of ammonia $\mathrm{N}$ into the rumen-ammonia pool is evidence of degradation of microbial nitrogenous compounds within the rumen. Approximately $30-40 \%$ of the microbial cells were estimated to be degraded in the rumen in these studies. Lysis of micro-organisms (Jarvis, I 968) may be a result of bacteriophage action (Adams, Gazaway, Brailsford, Hartman \& Jacobson, r966; Hoogenraad, Hird, Holmes \& Millis, 1967), predation of bacteria by protozoa (Coleman, 1964) or death of bacteria from other causes (Hungate, 1966).

Ammonia production in the rumen has been measured directly in three studies (see Pilgrim et al. I970; Mathison \& Milligan, I97ı; Nolan \& Leng, I972). The concentration of ammonia in rumen fluid of sheep fed roughage diets varied between 60 and $290 \mathrm{mg} \mathrm{N} / 1$ but the ammonia irreversibly lost was approximately constant at II $\mathrm{g} \mathrm{N} / \mathrm{d}(8-\mathrm{I} 7 \mathrm{~g})$ in all three studies. At this production rate, Nolan \& Leng (1972) calculated that $2 \mathrm{~g} / \mathrm{d}$ of ammonia $\mathrm{N}$ was being either absorbed directly or passed down the tract and absorbed. Since this quantity of ammonia $N$ can be readily accounted for in the movement of fluid out of the rumen, little ammonia was apparently absorbed directly from the rumen. Lack of ammonia absorption through the rumen wall of sheep fed these diets is also suggested by the large variation in concentration of ammonia in the rumen compared with the relative constancy of estimates of the irreversible loss of ammonia. If little ammonia is absorbed from the rumen, the large variation in ammonia concentrations is a result of a change in either the rate of passage of ammonia in fluid leaving the rumen or in the assimilation of ammonia by the rumen organisms.

\section{Post-ruminal metabolism of nitrogenous compounds}

Nitrogenous compounds in the rumen move with the digesta to the lower tract. Ammonia may be absorbed from the omasum although high concentrations of ammonia are present in abomasal and duodenal fluid. Unfermented feed and microbial cells move to the small intestine where appreciable proportions of their $\mathrm{N}$ compounds are digested and absorbed. Endogenous proteins, including mucoproteins and enzymes, entering the small intestines are also largely reabsorbed before they enter the ileum.

Urea probably enters the small intestine in digestive secretions and P. Kemp and J. V. Nolan (unpublished observations) have shown that in anaesthetized sheep the urea concentration in digesta between the duodenum and upper ileum approximated to that in blood. Hecker (1971) showed that urea was present in ileum-fluid 
samples from sheep and other workers have demonstrated that appreciable quantities of ammonia but little urea passed the proximal duodenum and terminal ileum in the digesta (Clarke, Ellinger \& Phillipson, I966; see also Coelho da Silva, Seeley, Thomson, Beever \& Armstrong, 1972). The origin of ileal ammonia is unknown but it may result from hydrolysis of urea that enters the ileum either from the upper tract or directly from blood since Hecker (I97I) and Sidhu, Jones \& Tillman (1968) have reported urease activity in the ileum. The amounts of ammonia passing out of the ileum to the caecum are similar to the quantities of $\mathrm{N}$ added to the ammonia pool in the caecum from blood urea (see below).

\section{Metabolism of nitrogenous compounds in the large intestine}

The extent of fermentation in the caecum of sheep fed diets of dried forages appears to be about $10 \%$ of that in the rumen as indicated by the rate of production of VFA (Faichney, I969) and methane (Leng \& Murray, 1972).

The $\mathrm{N}$ necessary for microbial growth in the caecum is available from undigested feed $N$, rumen microbial $N$, endogenous protein and ammonia and urea passing from the ileum and perhaps urea entering the caecum directly from blood. In recent unpublished studies from our laboratories with sheep given lucerne diets, the extent of ammonia production in the caecum and the contribution of blood urea to caecum-fluid ammonia were examined in ways similar to those used previously to study rumen-ammonia metabolism (Nolan \& Leng, I972). The caecum-ammonia production rate (i.e. the irreversible loss rate) was $4 \cdot 2 \mathrm{~g} \mathrm{~N} / \mathrm{d}$ of which $32 \%(\mathrm{I} \cdot 3 \mathrm{~g}$ $\mathrm{N} / \mathrm{d}$ ) was derived from blood urea (Table $\mathrm{I}$ ). The latter rate is similar to the estimated rate of flow of ammonia $\mathrm{N}$, of unknown origin, from the ileum of sheep given

Table r. Dynamics of nitrogen metabolism in sheep given a daily ration of $800 \mathrm{~g}$ lucerne chaff in equal portions at hourly intervals (values in $g N / d$ )

\begin{tabular}{|c|c|}
\hline Dietary $\mathrm{N}$ intake & 20 \\
\hline Rate of irreversible loss of urea from blood & 13.5 \\
\hline Rate of excretion of urea in the urine & $8 \cdot 0$ \\
\hline Rate of irreversible loss of ammonia from the rumen ammonia pool & $10 \cdot 5$ \\
\hline Rate of irreversible loss of urea from the caecum & $4 \cdot 2$ \\
\hline $\begin{array}{l}\text { Contribution of plasma urea to: } \\
\text { rumen ammonia } \mathrm{N} \\
\text { caecum ammonia } \mathrm{N}\end{array}$ & $\begin{array}{l}1 \cdot 2 \\
1 \cdot 3\end{array}$ \\
\hline $\begin{array}{l}\text { Contribution of rumen ammonia to: } \\
\text { plasma urea } N \text { (up to } 3 \mathrm{~h} \text { ) } \\
\text { plasma urea } N \text { (up to } 3 \mathrm{~d} \text { ) }\end{array}$ & $\begin{array}{l}1 \cdot 8 \\
7 \cdot 4\end{array}$ \\
\hline $\begin{array}{l}\text { Contribution of caecum ammonia to: } \\
\text { plasma urea } N \text { (up to } 3 \mathrm{~h} \text { ) } \\
\text { plasma urea } N \text { (up to } 3 \mathrm{~d} \text { ) }\end{array}$ & $\begin{array}{l}0.5 \\
x \cdot 7\end{array}$ \\
\hline
\end{tabular}

lucerne diets (Coelho da Silva et al. 1972). These results indicate that a large proportion $(68 \%$ or $2.9 \mathrm{~g} \mathrm{~N} / \mathrm{d}$ ) of caecum ammonia was not derived directly from blood urea but rather from other nitrogenous compounds passing from the small intestine: some of these compounds are known to have been synthesized from ammonia by micro-organisms in the rumen (unpublished observations). 
The extent of urea degradation in the small intestine is probably small relative to that occurring in the whole of the large intestine. This is supported by observations that $\left[{ }^{15} \mathrm{~N}\right]$-ammonia appears much sooner in faecal $\mathrm{N}$ after injection of $\left[{ }^{15} \mathrm{~N}\right]$-urea into blood than could be accounted for by passage of ${ }^{15} \mathrm{~N}$-labelled micro-organisms from the caecum to the rectum (unpublished observations).

\section{Metabolism of endogenous urea}

Because of the probable importance for fermentation of urea entering the gut from blood, the magnitude of urea movement into the rumen has been studied extensively. In tracer studies with intact animals in these laboratories, estimates of endogenous urea entering the rumen have been much smaller than estimates derived from direct methods using preparations of the rumen, or rumen pouches (see Houpt, 1970). In addition Nolan \& Leng (1972) found the rate of degradation of urea in the rumen was relatively minor in relation to the total rate of degradation in the body (see Cocimano \& Leng, I967).

The extent of the contribution of salivary urea- $\mathrm{N}$ to the ammonia- $\mathrm{N}$ pool is controlled by the saliva flow. Estimates of saliva flow in sheep have varied from 6$301 / \mathrm{d}$ (see Kay \& Hobson, 1963 ; Wilson, 1963 ) and in our studies with sheep given a lucerne diet, assuming that salivary urea concentrations are $60 \%$ of those in blood (Somers, $196 \mathrm{r}$ ), all the urea $\mathrm{N}$ entering the rumen would be accounted for by a flow rate of saliva of $8 \mathrm{l} / \mathrm{d}$. Arterio-venous differences of urea in blood across the rumen have also suggested that there is no movement of urea from the blood through the rumen wall in sheep on lucerne diets (Hecker \& Nolan, 1971). In contrast, studies with isolated rumen preparations have often indicated considerable urea movement across the rumen wall and these findings have led to much speculation concerning possible transport mechanisms (Houpt, 1970). Such studies have often involved experiments in which urea was infused to give unphysiological levels of urea in blood. Studies using isolated pouches of rumen epithelium are open to criticism because of the abnormal nature of the 'organ' and therefore extrapolation to the organ in the animal is of doubtful validity. Houpt \& Houpt (1968) noticed 'a slight dimunition of the cornified layer of the rumen epithelium' in pouch studies with goats some time after the studies were completed. When this cornified layer was disrupted with alkali the rate of entry of urea into the pouch was increased some fifty times.

The net gain of $\mathrm{N}$ between the mouth and duodenum (estimated with re-entrant cannulas) has been considerably greater than the urea- $\mathrm{N}$ entry into the rumen as measured by isotope dilution methods; values for sheep on a variety of diets have varied from $-5 \mathrm{~g}$ to $+13 \mathrm{~g} \mathrm{~N} / \mathrm{d}$. Of this probably $\mathrm{I}-2 \mathrm{~g} \mathrm{~N} / \mathrm{d}$ arises as proteins in secretions into the abomasum (Clarke et al. 1966) and if 51 of abomasal fluid are secreted daily in sheep on a maintenance diet, a further $\mathrm{I} \mathrm{g} / \mathrm{d}$ may enter as urea. The results of Benavides, Peron, Carillo, Alerma \& Preston (I972) show that protein additions in the digestive secretions can be high, but this may depend on the position of the cannulas in the duodenum. The extent of endogenous protein addition to the ingesta made by epithelial cells sloughed off the tract and by other sources added 
between the mouth and duodenum has not been estimated. Hume, Moir \& Somers (1970) gave sheep purified diets in which all the $N$ was supplied as urea and found that the total $\mathrm{N}$ passed to the omasum contained $4 \mathrm{~g}$ more than entered in the feed. This addition could be due solely to additions of $\mathrm{N}$ in saliva on the basis that the entry of $\mathrm{N}$ in saliva could be between $\mathrm{I}-5 \mathrm{~g} / \mathrm{d}$ if all $\mathrm{N}$ sources were considered (Phillipson, 1964).

The studies on caecum-ammonia metabolism further support the conclusion that the tract distal to the rumen is the major site of urea degradation in the sheep but less than $50 \%$ of the urea degradation has been accounted for in sites so far examined (Tables $\mathrm{I}$ and 2). Therefore degradation of urea in the large intestine distal to the caecum and/or in the small intestine must be considerable unless total urea degradation in the body is over-estimated.

Table 2. Rates of degradation of urea from blood ( $\mathrm{g}$ nitrogen $/ d$ ) in various parts of the digestive tract
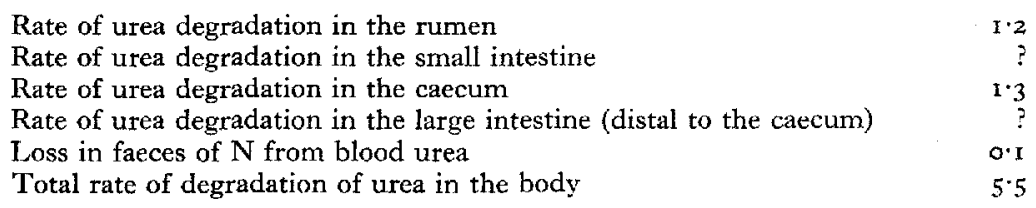

It is possible that urea is hydrolysed to ammonia in the rumen epithelium by bacterial urease (Abdel Rahman \& Decker, I966) and is reabsorbed without entering the rumen-ammonia pool, resulting in an over-estimation of the rate of degradation of urea in the gut. However, this is not indicated by dual isotope studies with $\left[{ }^{14} \mathrm{C}\right]$ - and $\left[{ }^{15} \mathrm{~N}\right]$-urea (Nolan \& Leng, 1972) nor by studies on arterio-venous differences of blood urea across the rumen (Hecker \& Nolan, 1971). Furthermore if losses of urea other than in urine (e.g. sweat) are high this could also cause overestimation of the rate of urea degradation. These losses are, however, thought to be negligible.

\section{Conclusions}

There appears to be a need for further studies on $\mathrm{N}$ cycling in intact ruminants before the processes involved are understood. In this paper it has been emphasized that urea enters both the upper and lower regions of the alimentary tract, probably in secretions, and that the lower tract appears to be the region where most urea is degraded. Urea- $\mathrm{N}$ entry into the digestive tract results in availability of $\mathrm{N}$ as ammonia in areas of bacterial growth in the digestive tract. It also results in a continuous absorption of ammonia which may supply ammonia for anabolic processes in the liver.

It has been definitely shown that, in isolated preparations, urea from blood can enter the rumen through the epithelium (see Thorlacius, Dobson \& Sellers, I971). However, the amounts moving into the rumen are considerably less than estimates previously reported and saliva appears to be the main route in intact animals. The 
contribution of $\mathrm{N}$ from other sources such as endogenous proteins may therefore be quantitatively more important for microbial synthesis when the dietary $\mathrm{N}$ is limiting.

Major differences between results obtained with isolated preparations and in intact animals have been stressed, and unless the latter studies are extended to animals in actual production systems, it cannot be assumed that the conclusions are applicable to animal production.

\section{REFERENCES}

Abdel Rahman, S, \& Decker, P. (1966). Nature, Lond. 209, 618.

Abe, M. \& Kandatsu, M. (1969). Fap. f. zootech. Sci. 40, 313.

Adams, J. C., Gazaway, J. A. Jr, Brailsford, M. D., Hartman, P. A. \& Jacobson, N. L. (1966). Experientia 22, 717 .

Benavides, M., Peron, N., Carillo, O., Alerma, A. \& Preston, T. R. (1972). Revta cub. Cienc. agric. (Engl. ed.) 5, 247 .

Clarke, E. M. W., Ellinger, H. M. \& Phillipson, A. T. (1966). Proc. R. Soc. B x66, 63.

Cocimano, M. R. \& Leng, R. A. (1967). Br. F. Nutr. 21, 353 .

Coelho da Silva, J. F., Seeley, R. C., Thomson, D. J., Beever, D. E. \& Armstrong, D. G. (1972). Br. F. Nutr, 28, 43 .

Coleman, G. S. (1964), F. gen. Microbiol. 37, 209.

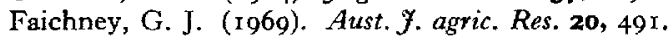

Hecker, J. F. (1971). Br. F. Nutr. 25, 85.

Hecker, J. F. \& Nolan, J. V. (1971). Aust. F. biol. Sci. 24, 403.

Hogan, J. P. \& Weston, R. H. (1970). In Physiology of Digestion and Metabolism in the Ruminant p. 474 [A. T. Phillipson, editor]. Newcastle upon Tyne: Oriel Press.

Hoogenraad, N. J., Hird, F. J. R., Holmes, I. \& Millis, N. F. (I967). F. gen. Virol. 1, 575.

Houpt, T. R. (1970). In Physiology of Digestion and Metabolism in the Ruminant p. 119 [A. T. Phillipson, editor]. Newcastle upon Tyne: Oriel Press.

Houpt, T. R. \& Houpt, K. A. (1968). Am. F. Physiol. 214, 1296.

Hume, I. D., Moir, R. J. \& Somers, M. (1970). Aust. J. agric. Res. 21, 283.

Hungate, R. E. (1966). The Rumen and Its Microbes. New York: Academic Press.

Jarvis, B. D. W. (1968). Appl. Microbiol. 16, 714.

Kay, R. N. B. \& Hobson, P. N. (x963). F. Dairy Res. 30, $26 \mathrm{I}$.

Leng, R. A. \& Murray, R. M. (1972). In Tracer Studies an Non-protein Nitrogen for Ruminants p. 302. Vienna: International Atomic Energy Agency.

Mathison, G. W. \& Milligan, L. P. (1971). Br. F. Nutr. 25, 35 I.

Nolan, J. V. \& Leng, R. A. (1972). Br. F. Nutr. 27, 177.

Phillipson, A. T. (1964). In Mammalian Protein Metabolism Vol. I, p. 7 I [H. N. Munro and J. B. Allison, editors]. London: Academic Press.

Pilgrim, A. F., Gray, F. V., Weller, R. A. \& Belling, C. B. (1970). Br. Y. Nutr. $24,589$.

Sidhu, K. S., Jones, E. W. \& Tillman, A. D. (1968). F. Anim. Sci. 27, 1703.

Somers, M. (1961). Aust. Y. exp. Biol. med. Sci. 39, I I I.

Thorlacius, S. O., Dobson, A. \& Sellers, A. F. (1971). Am. J. Physiol. 220, 62.

Wilson, A. D. (1963). Aust. F. agric. Res. 14, 808. 